\title{
ANALISIS FAKTOR-FAKTOR YANG MEMPENGARUHI PRODUKSI USAHATANI BUNCIS DI GABUNGAN KELOMPOK TANI LEMBANG AGRI KABUPATEN BANDUNG BARAT
}

\section{(Analysis of Determinant Influencing Bean in Combined Group Lembang Agri Farmer District West Bandung)}

\author{
Fadilla Deviani $^{1}$, Dini Rochdiani ${ }^{1}$ dan Bobby Rachmat Saefudin ${ }^{2}$ \\ ${ }^{1}$ Program Studi Agribisnis, Fakultas Pertanian Universitas Padjadjaran \\ ${ }^{2}$ Pusat Penelitian Pangan, DRPMI, Universitas Padjadjaran \\ J1. Raya Bandung Sumedang KM. 21, Jatinangor, Sumedang, Indonesia \\ Email :fadilladeviani@gmail.com
}

Diterima 13 Oktober 2019, disetujui 7 November 2019

\begin{abstract}
ABSTRAK
Penelitian ini bertujuan untuk menganalisis faktor-faktor yang mempengaruhi produksi (luas lahan, tenaga kerja, modal, pupuk, pestisida dan benih) terhadap jumlah produksi usahatani buncis di Gabungan Kelompok Tani Lembang Agri. Penelitian ini dilakukan dengan metode survei dan penentuan tempat lokasi penelitian secara purposive. Metode pemilihan sampel dengan proportionate stratified random sampling dengan mengambil sampel dari setiap kelompok tani sehingga sampel yang digunakan berjumlah 65 responden. Analisis yang digunakan adalah fungsi produksi Cobb-Douglas. Hasil penelitian menunjukan bahwa faktor produksi yang berpengaruh nyata terhadap produksi usahatani buncis adalah modal, pestisida dan benih di Gabungan Kelompok Tani Lembang Agri.
\end{abstract}

Kata kunci : buncis, faktor produksi, produksi, usahatani

\begin{abstract}
This study aims to analyze the factors that affect production (land area, labor, capital, fertilizer, pesticides, and seeds) on the amount of bean farm production in the Lembang Agri Farmers Group. This research was conducted by the survey method and the determination of the location of the research purpose purposively. The method of selecting samples with proportionate stratified random sampling by taking samples from each farmer group so that the sample used amounted to 65 respondents. The analysis used is the Cobb-Douglas production function. The results of this study indicate that the factors of production that significantly affect the production of bean farming are capital, pesticides, and seeds in the Lembang Agri Farmers Group.
\end{abstract}

Keywords: bean, factors production, production, farm 


\section{PENDAHULUAN}

Sektor pertanian merupakan sektor yang paling penting di Indonesia sehingga dijadikan sebagai fondasi dalam pembangunannya. Salah satu subsektor pertanian yang memiliki peranan penting dalam menunjang pembangunan dan perekonomian nasional adalah subsektor hortikultura. Hal ini didukung oleh karakteristik lahan dan agroklimat serta sebaran wilayah yang luas memungkinkan wilayah Indonesia sebagai daerah yang sangat berpotensial untuk mengembangkan komoditas hortikultura.Peningkatan produksi buncis di Indonesia harus dilakukan secara intensif agar dapat memenuhi kebutuhan gizi dan konsumsi bagi masyarakat. Hal tersebut dapat diwujudkan dengan teknik budidaya yang tepat, melalui pengaturan populasi tanaman dan pemilihan varietas yang sesuai dengan lingkungan agar hasilnya optimal (Fajriah et al, 2018).

Produksi buncis di Indonesia mengalami kenaikan dari tahun ke tahun antara lain pada tahun 2016 produksi sebesar 275.152 ton dan pada tahun 2017 sebesar 279.041 ton (BPS, 2018). Berdasarkan luas panen buncis di Indonesia, provinsi Jawa Barat merupakan provinsi penghasil buncis tertinggi (BPS Tanaman Sayuran dan Semusim, 2018). Daerah Jawa Barat yang memiliki potensi cukup besar dalam pengembangan sayuran buncis adalah Kabupaten Bandung Barat. Budidaya buncis di Kabupaten Bandung Barat berkembang cukup baik karena didukung oleh tersedianya lahan subur dengan ketinggian yang bervariasi serta adanya sarana dan prasarana yang mendukung dalam peningkatan pengetahuan dalam budidaya sayuran buncis seperti Balai Penelitian Sayuran.

Salah satu kelompok yang yang berada di Kabupaten Bandung Barat yang memproduksi buncis adalah Gabungan Kelompok Tani Lembang Agri. Gabungan Kelompok Tani Lembang Agri merupakan kelompok yang menaungi dan membina petani agar menghasilkan sayuran yang berkualitas. Kelompok ini berada di desa Cikidang, Kecamatan Lembang, Kabupaten Bandung Barat. Gabungan Kelompok Tani Lembang Agri memiliki anggota kelompok tani sekitar 9 kelompok tani.

Gabungan Kelompok Tani Lembang Agri mengalami kendala dalam memenuhi kebutuhan buncis di pasar karena produksinya masih rendah. Bahwa dalam memenuhi permintaan pasar masih mengambil buncis dari petani-petani di sekitar Lembang. Buncis yang dihasilkan petani dari Gabungan Kelompok Tani (Gapoktan) masih belum bisa memenuhi permintaan pasar. Keterbatasan kemampuan petani mengolah tanaman buncis sehingga berdampak pada hasil produksi yang menurun.

Menurut Yusuf et al. (2014) bahwa produksi dan produktivitas tidak lepas dari faktor-faktor produksi yang dimiliki petani untuk meningkatkan produksi hasil panennya. Banyak faktor yang mempengaruhi produksi antara lain lahan, tenaga kerja, modal, pupuk, pestisida, bibit dan teknologi (Rahim dan Hastuti, 2007). Keberhasilan usahatani tidak hanya dilihat dari segi tingginya produksi yang dihasilkan, tetapi efisien tidaknya penggunaan faktor produksi usahatani tersebut. Kegiatan usahatani dapat meningkatkan produksi apabila produsen dapat mengelola faktor-faktor produksi secara efisien. Sehingga tidak hanya produktivitas yang meningkat tetapi juga keuntungan dapat dihasilkan secara maksimal (Purwanto, 2009).

Tujuan dari penelitian ini adalah 1) menganalisis faktor-faktor produksi (luas lahan, tenaga kerja, modal, pupuk, pestisida dan benih) terhadap jumlah produksi buncis di Gabungan Kelompok Tani Lembang Agri Kabupaten Bandung Barat, 2) mengetahui faktor yang paling berpengaruh terhadap produksi buncis di Gabungan Kelompok Tani Lembang Agri Kabupaten Bandung Barat.

\section{METODE PENELITIAN}

Penelitian ini menggunakan metode 
survei. Penelitian dilaksanakan di Gabungan Kelompok Tani Lembang Agri yang memiliki lokasi usahatani di Desa Cikidang Kecamatan Lembang Kabupaten Bandung Barat. Pemelihan tempat penelitian dilakukan secara sengaja atau purposive sampling berdasarkan pertimbangan tertentu. Penelitian ini secara sengaja memilih Kecamatan Lembang sebagai lokasi penelitian karena kondisi sumber daya alam cocok untuk budidaya buncis.

Populasi yang digunakan adalah seluruh anggota kelompok tani yang tergabung pada Gabungan Kelompok Tani Lembang Agri Kabupaten Bandung Barat. Jumlah populasi pada Gabungan Kelompok Tani Lembang Agri yaitu 185 orang. Berdasarkan rumus slovin maka ukuran sampel yang digunakan sebagai berikut :

$$
\begin{aligned}
& n=\frac{N}{1+N(\alpha)^{2}} \\
& n=\frac{185}{1+185(0,10)^{2}} \\
& \mathrm{n}=65
\end{aligned}
$$

Keterangan :

$$
\begin{array}{ll}
\mathrm{n} & =\text { Ukuran sampel } \\
\mathrm{N} & =\text { Ukuran populasi } \\
\alpha & =\text { standar error yang digunakan } 10 \%
\end{array}
$$

Hasil perhitungan sampel menggunakan rumus slovin didapatkan sebanyak 65 responden. Dilihat dari sumber datanya, pengumpulan data dapat menggunakan sumber primer dan sumber sekunder. Sumber primer adalah sumber data yang memberi data lansung kepada pengumpul data sedangkan data sekunder adalah sumber yang tidak langsung memberikan data kepengumpul data (Sugiyono, 2012). Data primer dari penelitian ini diperoleh dari hasil pengamatan, pengisian kuesioner dan hasil wawancara langsung kepada petani di Gabungan Kelompok Tani Lembang Agri Kabupaten Bandung Barat. Sedangkan data sekunder diperoleh dari dari jurnal, penelitian terdahulu yang terkait, publikasi dari Badan Pusat Statistik, Kementrian Pertanian, Dinas
Pertanian, dan media informasi lainnya yang berhubungan dengan penelitian.

Metode analisis data yang digunakan dalam penelitian ini menggunakan persamaan regresi dengan model fungsi produksi CobbDouglas dan uji penyimpangan terhadap asumsi klasik yang meliputi uji normalitas, uji heteroskedastisitas, dan uji multikolinearitas. Semua pengujian tersebut dilakukan menggunakan bantuan software SPSS.

Faktor-faktor yang mempengaruhi produksi buncis dianalisis dengan model fungsi produksi Cobb-Douglas dengan model persamaan :

$\mathrm{Ln} Y=\ln \mathrm{b} 0+\mathrm{b} 1 \operatorname{Ln} \mathrm{X} 1+\mathrm{b} 2 \operatorname{Ln} \mathrm{X} 2+\mathrm{b} 3 \operatorname{Ln}$ $\mathrm{X} 3+\mathrm{b} 4 \operatorname{Ln} \mathrm{X} 4+\mathrm{b} 5 \operatorname{Ln} \mathrm{X} 5+\mathrm{b} 6 \operatorname{Ln} \mathrm{X} 6+\varepsilon$

Keterangan:

Y : Produksi buncis $(\mathrm{kg})$

bo : Konstanta

b1-6 : Koefisien arah regresi masing-masing produksi X1....X6

X1 : Lahan(ha)

$\mathrm{X} 2$ : Jumlah tenaga kerja (HOK)

X3 : Modal (Rp)

$\mathrm{X} 4$ : Pupuk (kg)

$\mathrm{X} 5$ : Pestisida (kg)

X6 : Benih $(\mathrm{kg})$

$\varepsilon \quad$ : error

Persamaan yang telah diperoleh dilanjutkan dengan uji statistik yang terdiri dari uji koefisien determinansi, uji simultan $\mathrm{F}$ dan uji parsial T.

\section{HASIL DAN PEMBAHASAN}

\section{Keadaan Umum Daerah Penelitian}

Desa Cikidang merupakan salah satu desa yang terdapat di Kecamatan Lembang Kabupaten Bandung Barat. Luas wilayah Desa Cikidang yaitu 532,861 $\mathrm{Ha}$ dan $113 \mathrm{Ha}$ diantaranya digunakan sebagai lahan pertanian. Wilayah Desa Cikidang terdiri 4 dusun yaitu Kampung Pengkolan, Kampung Cireyod, Kampung Cikareumbi dan Kampung Sadang. Desa Cikidang terdiri dari 11 RW dan 48 RT.

Berdasarkan keadaan topografinya, Desa Cikidang merupakan wilayah Desa Cikidang 
berada pada $1.312-2.084 \mathrm{~m}$ dpl dengan keadaan curah hujan rata-rata $20 \mathrm{~mm} / \mathrm{serta}$ suhu rata-rata antara $14^{\circ} \mathrm{C}-25^{\circ} \mathrm{C}$ dengan kelembaban udara rata-rata $74-82 \%$ per tahun. Hal Tersebut sesuai dengan syarat tumbuh tanaman buncis menurut Pusat Penelitian dan Pengembangan Hortikultura bahwa tanaman buncis dapat tumbuh optimum pada suhu $20-25^{\circ} \mathrm{C}$ di ketinggian 1000-1500 m dpl, sehingga Desa Cikidang sangat cocok dijadikan wilayah pertanian.

\section{Karateristik Responden}

Gambaran umum karateristik responden petani di Gabungan Kelompok Tani Lembang Agri dikelompokan berdasarkan umur, tingkat pendidikan, jumlah tanggungan keluarga, dan pengalaman usahatani. Berdasarkan Tabel 1. bahwa petani responden yang berusia $30-49$

Tabel 1. Identitas Responden

\begin{tabular}{|c|c|c|c|}
\hline No. & $\begin{array}{l}\text { Karateristik } \\
\text { Responden }\end{array}$ & $\begin{array}{l}\text { Jumlah } \\
\text { (orang) }\end{array}$ & $\begin{array}{c}\text { Persentase } \\
(\%)\end{array}$ \\
\hline \multirow[t]{5}{*}{1.} & Umur (Thn) & & \\
\hline & $30-49$ & 37 & 57 \\
\hline & $50-64$ & 24 & 37 \\
\hline & $>65$ & 4 & 6 \\
\hline & Jumlah & 65 & 100 \\
\hline \multirow[t]{6}{*}{2.} & Tingkat & & \\
\hline & Pendidikan & & \\
\hline & SD & 55 & 85 \\
\hline & SMP & 6 & 9 \\
\hline & SMA & 4 & 6 \\
\hline & Jumlah & 65 & 100 \\
\hline \multirow[t]{7}{*}{3.} & Jumlah & & \\
\hline & tanggungan & & \\
\hline & 0 & 6 & 9 \\
\hline & $1-2$ & 41 & 63 \\
\hline & $3-4$ & 17 & 26 \\
\hline & $5-6$ & 1 & 2 \\
\hline & Jumlah & 65 & 100 \\
\hline \multirow[t]{5}{*}{4.} & Lama Bertani & & \\
\hline & $<10$ & 13 & 20 \\
\hline & $10-20$ & 27 & 42 \\
\hline & $>20$ & 25 & 32 \\
\hline & Jumlah & 65 & 100 \\
\hline
\end{tabular}

Sumber : Analisis Data Primer, 2019 tahun sebanyak 37 orang dan berusia 50-64 sebanyak 24 orang. Petani responden menunjukan kisaran dalam usia produktif. Berdasarkan hasil penelitian, umur petani merupakan salah satu faktor yang akan mempengaruhi tingkat produksi buncis. Para petani yang berada pada umur produktif yang memiliki kondisi yang optimal untuk meningkat hasil produksi.

Pendidikan merupakan salah satu faktor pembentukan pola pikir seseorang dalam menyikapi perubahan keadaan masyarakat. Tingkat pendidikan yang ditempuh seseorang berpengaruh terhadap kemampuan berfikir dan perkembangan wawasan seseorang. Semakin tinggi tingkat pendidikan seseorang semakin besar kemampuannya untuk mengadopsi inovasi (Kalauw et al, 2015). Berdasarkan hasil penelitian, bahwa petani responden mayoritas tingkat pendidikannya adalah lulusan sekolah dasar (SD) sebanyak 55 orang dengan persentase $85 \%$.

Jumlah tanggungan keluarga petani tertinggi yaitu berjumlah 1-2 orang sebanyak 41 orang atau sebesar $63 \%$. Semakin banyak jumlah anggota keluarga maka semakin tinggi peluang menjadi sumber tenaga kerja dalam keluarga. Namun Menurut Asih (2009) bahwa jumlah anggota keluarga merupakan tenaga kerja maka semakin tinggi pula biaya yang harus dikeluarkan untuk konsumsi dan semakin kecil dana yang dapat dialokasikan untuk biaya usahatani.

Jumlah petani responden yang memiliki pengalaman berusahatani 10-20 tahun sebanyak 27 orang atau sebesar $42 \%$. Pengalaman usahatani sangat mempengaruhi petani dalam menjalankan usahatani. Semakin lama seseorang melakukan usahatani, maka semakin berkembang pula keterampilan yang dimilikinya. Dapat disimpulkan bahwa usahatani buncis di Desa Cikidang merupakan usahatani sejak dulu dikembangkan dan dibudidayakan oleh masyarakat.

Modal dalam usahatani didefinisikan sebagai bentuk kekayaan, baik berupa uang atau barang yang digunakan untuk menghasilkan sesuatu baik secara langsung maupun tidak langsung dalam suatu proses 
produksi (Soekartawi, 2003). Dalam usahatani buncis berdasarkan penelitian, bahwa petani rata-rata menggunakan modal sendiri. Rata-rata modal yang dikeluarkan petani untuk usahatani buncis adalah sekitar Rp. 6.000.000 dalam satu kali musim tanam.

Fungsi produksi yang digunakan untuk melihat faktor-faktor yang mempengaruhi usahatani buncis adalah fungsi CobbDouglass dengan variabel terikat yaitu produksi buncis $(\mathrm{Y})$ dan variabel bebas yaitu luas lahan $\left(\mathrm{X}_{1}\right)$, tenaga kerja $\left(\mathrm{X}_{2}\right)$, modal $\left(\mathrm{X}_{3}\right)$, pupuk $\left(\mathrm{X}_{4}\right)$, pestisida $\left(\mathrm{X}_{5}\right)$, dan benih $\left(\mathrm{X}_{6}\right)$. Berdasarkan perhitungan data menggunakan

Tabel 2. Hasil Uji Signifikansi Koefisien Faktor-faktor Produksi Usahatani Buncis

\begin{tabular}{lccc}
\hline \multicolumn{3}{l}{ Variabel } & $\begin{array}{l}\text { Koefisien } \\
\text { Regresi }\end{array}$ \\
\multicolumn{3}{c}{-hitung } & $\mathrm{p}$-value \\
Konstanta & 1,801 & 4,890 & 0,000 \\
$\begin{array}{l}\text { Lahan } \\
\left(\mathrm{X}_{1}\right)\end{array}$ & 0,076 & 1,347 & 0,183 \\
Tenaga & $-0,139$ & $-1,248$ & 0,217 \\
kerja $\left(\mathrm{X}_{2}\right)$ & & & \\
Modal & 0,161 & 3,082 & $0,003^{* *}$ \\
$\left(\mathrm{X}_{3}\right)$ & & & \\
Pupuk & 0,053 & 1,031 & 0,307 \\
$\left(\mathrm{X}_{4}\right)$ & & & \\
Pestisida & $-0,290$ & $-3,968$ & $0,000^{* *}$ \\
$\left(\mathrm{X}_{5}\right)$ & & & \\
Benih & 0,957 & 11,940 & $0,000^{* *}$ \\
$\left(\mathrm{X}_{6}\right)$ & & & \\
$\mathrm{F}$ hitung & & & 0,000 \\
$=46,138$ & & & \\
$\mathrm{R}^{2}=0,837$ & & & \\
\hline
\end{tabular}

Sumber : Analisis Data Primer, 2019.

Keterangan: **: signifikansi pada taraf $95 \%$

aplikasi SPSS versi 24 didapatkan hasil seperti terlihat pada Tabel 2.

Tabel 2. menujukkan bahwa model fungsi produksi buncis diperoleh persamaan sebagai berikut :

$$
\begin{aligned}
\operatorname{LnY}= & 1,801+0,076 \operatorname{LnX}_{1}-0,139 \operatorname{LnX}_{2}+ \\
& 0,161 \operatorname{LnX}_{3}+0,053 \operatorname{LnX}_{4}-0,290 \\
& \operatorname{LnX}_{5}+0,957 \operatorname{LnX}_{6}+\varepsilon
\end{aligned}
$$

Berdasarkan hasil uji asumsi klasik yaitu uji normalitas, uji heterokedastisitas dan uji multikolinearitas. Uji normalitas dilakukan dengan one sample Kolmogorov-Smirnov Test diperoleh nilai Asymp. Sig sebesar 0,200 > 0,05 sehingga data yang diuji berdistribusi normal. Menurut Ghozali (2011), uji heteroskedastisitas bertujuan untuk menguji apakah dalam model regresi terdapat ketidaksamaan varians dari residual satu pengamatan ke pengamatan lain.Uji heteroskedastisitas dilakukan dengan melihat pola sebaran titik-titik pada diagram scatterplot (Priyatno, 2009). Berdasarkan Ilustrasi 1. bahwa bahwa titik-titik menyebar dan tidak membentuk pola tertentu yang jelas. Sehingga dapat disimpulkan bahwa tidak terjadi gejala heteroskedastisitas. Hasil uji multikolinearitas bahwa data tidak mengalami gejala multikolinearitas karena VIF semua

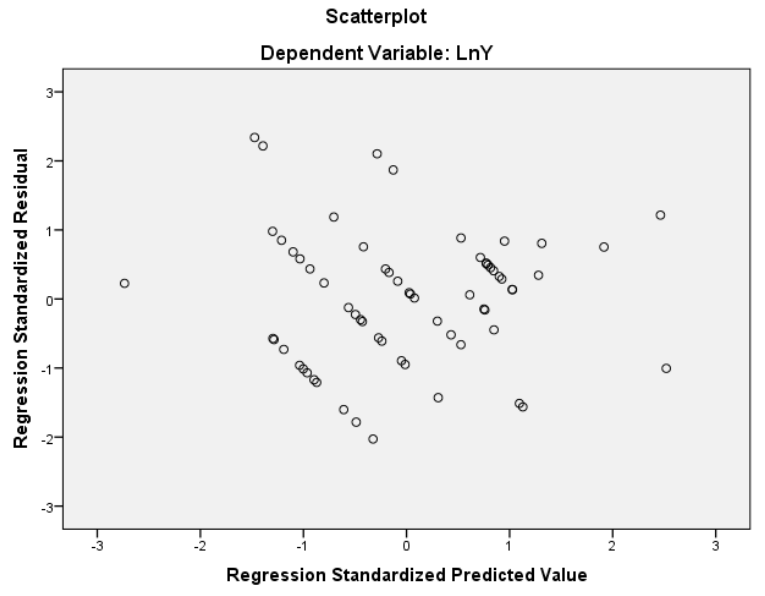

Ilustrasi 1. Diagram Scatterplot

Sumber: Data diolah Primer, 2019

variabel kurang dari 10. Nilai VIF $\mathrm{X}_{1}$ hingga $\mathrm{X}_{6}$ secara berturut-turut adalah 2,918, 1,537, $1,382,1,217,1,713$, dan 1,913. Menurut Gujarati (2003) menyatakan bahwa uji multikolinearitas dapat dilihat dari output coliniearity statistic. Jika nilai VIF $<10$ maka tidak terjadi multikolinearitas.

Berdasarkan hasil analisis uji koefisien determinansi $\left(\mathrm{R}^{2}\right)$ diperoleh nilai $\mathrm{R}^{2}$ sebesar 0,837 . Hal ini berarti variasi produksi buncis dapat diterangkan oleh variasi faktor-faktor produksi sebesar $83,7 \%$. Hal ini berarti bahwa kemampuan variabel bebas yang dimasukan 
dalam model fungsi produksi yaitu lahan, tenaga kerja, modal, pupuk, pestisida dan benih mempunyai pengaruh yang cukup besar terhadap peningkatan produksi buncis sedangkan sisanya sebesar $16,3 \%$ dipengaruhi oleh faktor-faktor lain seperti kondisi alam, hama dan penyakit serta variabel lain yang tidak dimasukan ke dalam model ini.

Berdasarkan hasil analisis uji $\mathrm{F}$ diperoleh nilai $F$ hitung sebesar 46,183 dan nilai signifikan sebesar 0,000 , dengan tingkat signifikansi yang digunakan sebesar 0,05 sehingga penggunaan faktor produksi luas lahan, tenaga kerja, modal, pupuk, pestisida dan bibit secara bersama-sama berpangaruh nyata terhadap produksi buncis. Berdasarkan hasil analisis uji $\mathrm{t}$ dapat diketahui bahwa secara parsial bahwa modal, pestisida dan benih berpengaruh nyata $(p<0,05)$ terhadap produksi buncis sedangkan luas lahan, tenaga kerja dan pupuk tidak berpengaruh nyata $(\mathrm{p}>0,05)$ terhadap produksi buncis.

\section{Luas Lahan $\left(\mathbf{X}_{1}\right)$}

Hasil analisis uji parsial yang telah dilakukan bahwa nilai koefisien luas lahan yaitu sebesar 0,076. Nilai koefisien tersebut menunjukkan bahwa antara produksi buncis dan lahan memiliki hubungan yang positif atau searah. Bahwa setiap peningkatan luas lahan sebesar $1 \%$ dengan menganggap faktor lain tetap (cateris paribus) maka akan mengalami peningkatan jumlah produksi buncis sebesar 0,076\%. Berdasarkan hasil pendugaan parameter variabel lahan memiliki p-value sebesar 0,076 dengan tingkat signifikansi 0,05 , hal ini menunjukkan bahwa luas lahan tidak berpengaruh nyata terhadap produksi buncis. Menurut Rasmikayati et al. (2019) bahwa status kepemilikan lahan tidak hanya mempengaruhi luas lahan tetapi mempengaruhi pendapataan. Berdasarkan hasil penelitian, bahwa luas lahan yang dimiliki petani rata-rata masuk kategori lahan skala kecil. Apabila dilakukan penambahan luas lahan untuk meningkatkan produksi buncis bagi petani tidak mudah karena semakin besar luas lahan yang dimiliki petani maka modal yang dikeluarkan untuk memproduksi buncis pun semakin besar. Padahal, petani memiliki modal yang terbatas sehingga hal ini sangat sulit dilakukan oleh petani.

\section{Tenaga Kerja $\left(\mathbf{X}_{2}\right)$}

Hasil analisis uji parsial yang telah dilakukan bahwa nilai koefisien tenaga kerja yaitu sebesar -0,319. Nilai koefisien tersebut menunjukkan bahwa antara produksi buncis dan tenaga kerja memiliki hubungan yang negatif atau tidak searah. Bahwa setiap peningkatan tenaga kerja sebesar $1 \%$ dengan menganggap faktor lain tetap (cateris paribus) maka akan diikuti penurunan jumlah produksi buncis sebesar 0,319\%. Berdasarkan hasil pendugaan parameter variabel tenaga kerja memiliki $p$-value sebesar 0,217 dengan tingkat sigbifikansi 0,005 , hal ini menunjukan bahwa tenaga kerja tidak berpengaruh nyata terhadap produksi buncis. Berdasarkan informasi yang didapat dari hasil wawancara dengan petani, bahwa penggunaan tenaga kerja dalam produksi buncis di Gabungan Kelompok Tani Lembang Agri paling banyak menggunakan tenaga kerja dalam keluarga. Tenaga kerja sangat dibutuhkan dalam setiap kegiatan budidaya buncis mulai dari pengolahan lahan sampai panen tetapi petani yang menjadi responden hanya membutuhkan tenaga kerja luar keluarga pada saat panen saja karena proses pemanenan dilakukan 2 minggu sekali dimana setiap panen menghasilkan 1 kuintal sehingga dibutuhkan tenaga kerja luar keluarga untuk membantu proses pemanenan. Menurut Neonbota (2016) bahwa penggunaan tenaga kerja tentunya harus cermat dan benar-benar diperhitungkan. Hal ini dapat dilihat bahwa tenaga kerja tidak berpengaruh terhadap peningkatan produksi buncis.

\section{Modal $\left(\mathbf{X}_{3}\right)$}

Modal yang dimaksud dalam penelitian ini berupa biaya yang dikeluarkan dalam memenuhi faktor-faktor produksi dalam usahatani buncis. Rata-rata besar modal yang dikeluarkan petani dalam usahatani buncis sekitar Rp 6.000.000 dalam satu kali musim 
tanam. Hasil analisis uji parsial yang telah dilakukan bahwa nilai koefisien modal yaitu sebesar 0,161. Nilai koefisien tersebut menunjukkan bahwa antara produksi buncis dan modal memiliki hubungan yang positif atau searah. Bahwa setiap peningkatan modal sebesar $1 \%$ dengan menganggap faktor lain tetap (cateris paribus) maka akan mengalami peningkatan jumlah produksi buncis sebesar $0,161 \%$. Berdasarkan hasil pendugaan parameter variabel modal memiliki $p$-value sebesar 0,003 dengan tingkat signifikansi 0,05 , hal ini menunjukkan bahwa modal berpengaruh nyata terhadap produksi buncis. Berdasarkan hasil penelitian, bahwa penggunaan modal pada petani dalam produksi buncis rata-rata menggunakan modal sendiri dan dalam budidaya buncis pun tidak memerlukan modal yang besar karena tanaman buncis sangat kuat akan perubahan cuaca sehingga pestisida yang digunakan pun sedikit dan juga perawatan pada buncis tidak terlalu susah. Hal ini dapat dilihat bahwa dalam penggunaan modal seefisien akan berpengaruh terhadap peningkatan produksi buncis.

\section{Pupuk $\left(\mathbf{X}_{4}\right)$}

Hasil analisis uji parsial yang telah dilakukan bahwa nilai koefisien pupuk yaitu sebesar 0,053. Nilai koefisien tersebut menunjukan bahwa antara produksi buncis dan pupuk memiliki hubungan yang positif atau searah. Bahwa setiap peningkatan pupuk sebesar $1 \%$ dengan menganggap faktor lain tetap (cateris paribus) maka akan mengalami peningkatan jumlah produksi buncis sebesar $0,053 \%$. Berdasarkan hasil pendugaan parameter variabel lahan memiliki $p$-value sebesar 0,307 dengan tingkat signifikansi 0,05 , hal ini menunjukkan bahwa pupuk tidak berpengaruh nyata terhadap produksi buncis. Berdasarkan informasi yang didapat dari hasil wawancara, bahwa rata-rara petani menggunakan pupuk kandang dan pupuk NPK untuk produksi buncis. Penggunaan pupuk kandang, rata-rata petani dalam $1 \mathrm{Ha}$ per musim tanam yaitu sebanyak $8.000 \mathrm{~kg}$ atau 8 ton dan penggunaan pupuk NPK sebanyak $50 \mathrm{~kg} / \mathrm{Ha}$. Berdasarkan petunjuk teknis budidaya buncis yang dikeluarkan oleh Litbang Pertanian Tahun 2013, bahwa penggunaan pupuk pada budidaya buncis yaitu pupuk kandang sekitar 15 ton/Ha dan pupuk NPK sebanyak $300 \mathrm{~kg} / \mathrm{Ha}$. Pupuk kandang yang mengandung unsur hara yang tinggi adalah kotoran ayam. Kandungan unsur hara pupuk kandang ayam tiga kali lebih besar dari hewan ternak lainnya (Musnamar, 2003). Hal ini sesuai dengan pendapat Saputra et al. (2018) menyatakan bahwa pemberian pupuk organik / ppuk kandang dalam jumlah yang banyak tidak akan membawa dampak negatif bagi tanaman, karena pupuk organik menyuplai unsur hara secara perlahan dan kontinu. Dapat dilihat bahwa petani dalam penggunaan pupuk tidak sesuai petunjuk karena untuk menghemat biaya yang dikeluarkan dalam penggunaan pupuk.

\section{Pestisida $\left(\mathbf{X}_{5}\right)$}

Hasil analisis uji parsial yang telah dilakukan bahwa nilai koefisien pestisida yaitu sebesar -0,290. Nilai koefisien tersebut menunjukan bahwa antara produksi buncis dan pestisida memiliki hubungan yang negatif atau tidak searah. Bahwa setiap peningkatan pestisida sebesar $1 \%$ dengan menganggap faktor lain tetap (cateris paribus) maka produksi buncis akan mengalami penurunan sebesar 0,290\%. Berdasarkan hasil pendugaan parameter variabel pestisida memiliki $p$-value sebesar 0,000 dengan tingkat signifikansi 0,05 . Hal ini menunjukkan bahwa pestisida berpengaruh nyata terhadap produksi buncis. Hama dan penyakit merupakan salah satu faktor yang menghambat peningkatan produksi buncis. Berdasarkan informasi dari hasil wawancara dengan petani, bahwa penggunan pestisida dilakukan saat tanaman buncis sudah terlihat ada yg terserang hama dan penyakit. Menurut Litbang Pertanian tahun 2013 bahwa dalam penggunaan pestisida harus tepat pemilihan jenis, dosis, dan waktu aplikasinya. Hal ini sesuai dengan pendapat Susanti (2018) menyatakan bahwa penggunaan pestisida dapat bermanfaat untuk 
meningkatkan produksi pertanian apabila digunakan dengan dosis yang tepat dan dikelola dengan baik akan menimbulkan dampak yang positif.

\section{Benih $\left(\mathbf{X}_{6}\right)$}

Hasil analisis uji parsial yang telah dilakukan bahwa nilai koefisien benih yaitu sebesar 0,957. Nilai koefisien tersebut menunjukkan bahwa antara produksi buncis dan benih memiliki hubungan yang negatif atau tidak searah. Bahwa setiap peningkatan benih sebesar $1 \%$ dengan menganggap faktor lain tetap (cateris paribus) maka akan mengalami penurunan jumlah produksi buncis sebesar 0,957 \%. Berdasarkan hasil pendugaan parameter variabel lahan memiliki p-value sebesar 0,000 dengan tingkat signifikansi 0,05 , hal ini menunjukan bahwa benih berpengaruh nyata terhadap produksi buncis. Berdasarkan hasil wawancara, petani menggunakan benih varietas logawa. Logawa merupakan buncis tipe polong hijau dengan warna biji putih dimana cocok untuk ditanam di dataran menengah-tinggi. Dalam penanaman benih buncis, tiap lubang tanam dapat diisi 2-3 butir benih (Setianingsih dan Kherudin, 1993). Kondisi di lapangan, petani sudah melakukan sesuai dengan panduan yang ada yaitu setiap lubang tanam diisi dengan 2-3 butir benih. Hal ini dapat dilihat bahwa dalam penggunaan benih yang sesuai anjuran akan berpengaruh nyata pada peningkatan produksi buncis.

\section{SIMPULAN DAN SARAN}

Faktor produksi luas lahan, tenaga kerja, modal, pupuk, pestisida dan benih secara bersama-sama berpengaruh nyata terhadap produksi buncis dengan koefisien determinansi sebesar 0,837. Secara parsial, modal, pestisida dan benih berpengaruh nyata terhadap produksi buncis sedangkan luas lahan, tenaga kerja dan pupuk tidak berpengaruh nyata terhadap produksi buncis.

Berdasarkan hasil penelitian saran yang dapat diberikan adalah penggunaan faktor produksi pupuk ditambah karena penggunaan pupuk untuk memaksimalkan hasil produksi yang dihasilkan waktu panen sehingga dapat meningkatkan produksi buncis. Bantuan dari pemerintah berupa modal dan penyediaan sarana produksi untuk meningkatkan produksi usahatani masih sangat dibutuhkan.

\section{DAFTAR PUSTAKA}

Asih, D. N. 2009. Analisis karateristik dan tingkat pendapatan usahatani bawang merah di Sulawesi Tengah. J. Agroland. $16(1): 53-59$.

Badan Pusat Statistika. 2018. Tanaman Sayuran dan Buah-buahan Semusim. [Diakses pada 3 Agustus 2019].

Badan Pusat Statistika. 2018. Produk Domestik Bruto Indonesia Triwulan 2014-2018. [Diakses pada 3 Agustus 2019].

Fajriah, A. C., G. Haryono, dan Historiawati. 2018. Respon jumlah tanaman per lubang terhadap hasil varietas buncis (Phaseolus vulgaris, L.) tipe tegak. J. Ilmu Pertanian Tropika dan Subtropika. 3(2) : 36-39.

Ghozali, I. 2011. Aplikasi Analisis Multivariate dengan program IBM SPSS 19. Badan Penerbit Universitas Diponegoro, Semarang.

Gujarati, D. 2003. Ekonometri Dasar. Erlangga, Jakarta.

Kalauw, S. H. S., N. R Timisela, dan M. T. F. Tuhumury. 2015. Analisis faktor-faktor yang mempengaruhi produksi sayuran buncis (Phaseolus vulgaris L.) di Dusun Telaga Kodok Kabupaten Maluku Tengah. J. Agrilan. 3(2) : 140-156.

Musnamar, E. I. 2003. Pupuk Organik: Cair dan Padat, Pembuatan, Aplikasi. Penebar Swadaya, Jakarta.

Neonbota, S. L. dan S. J. Kune. 2016. Faktorfaktor yang mempengaruhi usahatani padi sawah di Desa Haekto Kecamatan Noemuti Timur. J. Agribisnis Lahan Kering. 1(3) : 32-35. 
Priyatno, D. 2009. Mandiri Belajar SPSS. Mediakom, Yogyakarta.

Pusat Penelitian dan Pengembangan Hortikultura. 2013. http://hortikultura.lit bang.pertanian.go.id/teknologi-detail46.html [Diakses pada 4 Agustus 2019]

Purwanto, T. 2009. Analisis Faktor-Faktor yang Memengaruhi Impor Kacang Kedelai Nasional Periode 1987-2007 Skripsi. Program Sarjana Institut Pertanian Bogor, Bogor.

Rahim, A. dan D. R. W. Hastuti. 2007. Ekonomi Pertanian. Penebar Swadaya, Jakarta.

Rasmikayati, E., E. A. Elfandina, dan B. R. Saefudin. 2019. Characteristic of mango farmers and factor associated with their land tenure area. International Journal of Scientific and Research Publication (IJSRP). 9(9) : 758-765.

Saputra, M. Y., H. G. Marwandha, dan T. Swandari. 2018. Pertumbuhan dan produksi buncis (Phaseolus vulgaris L.) dengan pemberian pupuk tandan kosong kelapa sawit dan NPK. J. Agroista. 2(2) : 151-161.

Setianingsih, T. dan Khaerudin. 1993. Pembudiyaan Buncis Tipe Tegak dan Merambat. PT Penebar Swadaya, Jakarta.

Soekartawi. 2003. Teori Ekonomi Produksi Dengan Pokok Bahasan Analisis Fungsi Cobb-Douglas. PT. Raja Grafindo Persada, Jakarta.

Sugiyono. 2012. Metode Penelitian Kuantitatif Kualitatif dan R\&D. Alfabeta, Bandung.

Susanti H., K. Budiraharjo dan M. Handayani. 2018. Analisis pengaruh faktor-faktor produksi terhadap produksi usahatani bawang merah di Kecamatan Wanasari Kabupaten Brebes. J. Agrisocionomics. 2(1) : 23-30.

Yusuf, H., Hasnudi, dan Y. Lubis. 2014. Analisis faktor-faktor yang mempengaruhi produksi jagung di Kabupaten Aceh Tenggara. J. Agrica. 7(2) : 65-73. 